\title{
A televisão Digital: concessionária de ilusões
}

\author{
Ivan Peñuela \\ Mestrando em Comunicação
}




\section{Resumo}

O artigo aborda aspectos relacionados à televisão aberta brasileira, que se encontra num processo de transição do sistema analógico para o digital. No entanto, destaca-se que apenas a adoção de um sistema mais eficaz e versátil não trará ao meio a eficácia comunicativa esperada, uma vez que sua programação, de um lado, está moldada a interesses comerciais e, de outro, regulada por políticas inadequadas. A televisão aberta chega a mais de $90 \%$ dos lares brasileiros, influenciando comportamentos de um povo com uma cultura miscigenada, o que enfatiza a necessidade de se reavaliar as práticas comunicativas deste meio.

\section{Palavras-chave}

televisão, analógico, digital e cultura midiática.

\section{Abstract}

The article approaches aspects related to the Brazilian open television, that if finds in a process of transition of the analogical system for the digital one. However, it is relevant to observe that only the adoption of a more efficient and versatile system will not guarantee its communicative effectiveness, mainly in a period in which television programs are molded by commercial interests. The open television reaches more than $90 \%$ of the Brazilian homes, influencing behaviors of a people with cultural mixtures. Thus it seems necessary to reevaluate the practical communicative of this media.

\section{Keywords}

television, analogical and digital systems and culture. 


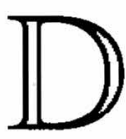

esde o seu nascimento em 1950, a mais significativa mudança tecnológica da TV aberta brasileira ocorreu em 1972, quando as imagens deixaram o preto e branco, passando a ser transmitidas em cores. Agora, 57 anos depois, o maior veículo de comunicação de massa do país vai transitar para o mundo digital. $\mathrm{O}$ código binário está chegando à TV aberta e, com ele, uma série de novas possibilidades que vão, desde a melhoria de qualidade de som e imagem, passando por uma suposta interatividade e culminando na convergência com outros aparelhos do mundo digital (celular, internet, etc.).

Sendo assim, não perderemos mais o capítulo da novela das oito quando estivermos em meio a um mega-congestionamento, já não exclusivo das metrópoles, mas também de um grande número de cidades brasileiras que trocaram charretes e cavalos por modernos e sofisticados veículos de duas ou quatro rodas. Estes são produzidos e distribuídos em massa, graças à colaboração dos "sonhos de consumo" vendidos, principalmente, pela publicidade televisiva.

Quando se fala aqui em charretes e cavalos, não se trata de fazer referência a uma visão nostálgica que se opõe ou nega muitos dos benefícios que advêm das novas tecnologias, mas sim, em termos mais humanos, da aplicação e usufruto delas. Aqui reside a nossa preocupação, o receio de que esta "mudança" na TV aberta fique limitada a uma melhoria de qualidade de sons e imagens, relegando a um plano secundário a reflexão sobre o paradigma funcional da comunicação do país que, logo de início, se finca em leis e decretos atidos, basicamente, às viabilidades técnicas e econômicas dos processos de implantação e concessões de canais dos meios de comunicação, centrando seus interesses no "como" da comunicação 
e, em detrimento da sua essência ou do seu porquê, aproximandose consideravelmente da "teoria funcionalista da comunicação". Isto é, assumindo uma "visão" pragmática em que a eficácia da comunicação se encontra num sistema de emissão e recepção de sinais sem ruídos, sem interferências, com a finalidade de que tudo chegue ao seu receptor com a maior qualidade técnica possível.

Na perspectiva de Malena Segura Contrera (2007), tal paradigma assenta fortemente seus fundamentos sobre os estudos da cibernética de Shannon e Weaver. E, por isso, as primeiras e principais reflexões dedicadas especificamente aos fenômenos comunicativos do século XX ficaram marcadas por uma visão tecnicista da comunicação, visão essa em que o ser humano era o ente resultante das referências com que se pensavam os até então recentes sistemas artificiais de informação. Ancorando-se em idéias de Rüdiger, quem destaca alguns dos efeitos negativos das concepções mecanicistas. Por um lado, a autora assinala que tal posição parece ignorar, sobretudo, a complexidade dos sistemas vivos e suas profundas diferenças com relação aos sistemas artificiais. Por outro, o pragmatismo a que essa tendência se vincula. Não há dúvida de que essa atitude, por razões históricas e ideológicas, se pergunta, quase sempre, pelos "comos" e jamais pelos "porquês". A prioridade dada aos "comos" parece ser, portanto, o alicerce do atual ethos reinante nas práticas comunicativas, quase sempre a serviço do compromisso utilitário de extrair o melhor proveito e a máxima eficiência das últimas parafernálias técnicas e tecnológicas, transformando-as em concessionárias exclusivas na venda de ilusões.

Cada vez mais, o mundo digital vai rompendo fronteiras a uma velocidade absurda, a internet, o telefone celular, a TV a cabo, os I-pods, enfim, tudo ganha velocidade e quantidade, para que o ser humano "ganhe" tempo, ${ }^{1}$ para que tenha mais opões do que fazer com seu tempo "livre". O que se diz por aí é que hoje podemos "chegar" à Europa ou ao Japão com um simples "click", mandar um

1. Mesmo que pareça uma constatação óbvia, talvez seja conveniente pensar que, se algo existe que não podemos acumular, é tempo. 
E-mail para o Papa, simular uma transa com a Madonna, tudo na rede virtual da WWW. As distâncias ficaram mais "curtas", porém as relações humanas mais distantes. Com tantos pixels, megapixels, megabytes e bytes, todos estamos ficando "bytolados" à frente de monitores de computador ou TV, buscando preencher os vazios das angústias que, muitas vezes, derivam de nossa solidão. Somos bandos de solitários espalhados em blogs por todo o planeta e às vezes esquecemos que a verdadeira comunicação, ou aquela que gostaríamos de ter, não passa de virtualidade. A esse respeito, vale à pena lembrar estas palavras de Marcondes Filho:

" $O$ vivo na comunicação está fora dos modelos, está fora da "comunicação", está, como vimos, nos olhares, cuja força, como dizia Törless, não cabe em nenhuma aula de Física. Está na paixão, num algo mais presente no abraço entre dois amantes que não querem ou não podem oficializar esse amor, no diálogo a-sígnico, extralingüístico, não significante dos olhares que se falam à margem, lateralmente à fala que está sendo proferida; dá-se quando estes se sabem amantes num amor que nenhum deles precise pronunciar palavra" (2004, p. 99).

A industrialização, a ascensão da burguesia, a relação do homem com o planeta, que passa a ser um instrumento de obtenção de lucro, geram o que Weber (1920) chamou de "desencantamento do mundo". Temos, desde então, um homem cada vez mais voltado a si, individualista e menos coletivo, um ser narcíseo que se revela à frente dos monitores, cada vez com mais conforto e comodidade num estado "hipnótico" de absorção de mensagens de uma "comunicação", quase sempre de uma só via. Enfim, um ser incomunicável.

Assumindo agora a primeira pessoa, tive a oportunidade de ouvir numa rádio, parte de um comentário de Jabor a respeito das ONG'S e dessa onda de preocupação com a preservação do planeta; tsunamis, aquecimento global, etc."O planeta vai seguir o seu caminho", dizia ele, "o planeta quer que o homem se "lasque", não 
depende dele pra continuar." ${ }^{\text {No }}$ campo da comunicação, neste caso, podemos observar nitidamente que a grande preocupação do homem é com ele mesmo e não com o planeta, o contrário do que se noticia na maioria desses movimentos, é nesse momento que a intenção acaba camuflada em seu sentido mais profundo. Soterra-se, assim, uma verdade que deveria se encontrar no íntimo de cada ser humano, e se ganha uma coletividade de pensamento ausentado de reflexão individual e, de uma forma quase "irrefletida", o indivíduo transfere a sua responsabilidade ao coletivo (Governos, ONG'S, Comunidade Científica, etc.). Nesse caso, nota-se uma situação de comunicação paradoxal, uma vez que a mensagem que deveria mobilizar cada indivíduo tem o efeito reverso, de acomodação e conforto, e esse mesmo indivíduo não abre mão das regalias do sistema que adotou para sobreviver. Um sistema que depende da exploração máxima e desenfreada dos recursos do planeta e, acorrentadas nele, as pessoas repetem aos celulares, em seus carros, que o planeta está "doente". "Doente" ele está na visão exclusiva do ser humano que atribui à sua condição de morte a de morte do planeta. Ou como sintetiza a questão Ciro Marcondes Filho:

"Os relacionamentos humanos trabalham contra a comunicação. Grandes sistemas sociais (rádios, televisões, jornais, revistas, divulgação pública e comercial) difundem mensagens diversas, mas não comunicam. Pessoas cumprimentam-se diariamente, trocam-se algumas palavras, mas não se comunicam. As formas modernas de contato entre as pessoas, as imagens de cada um que podem ser veiculadas pela internet, os telefones celulares, as câmeras que capacitam qualquer um a fazer um filme sugerem que as pessoas assim aproximem-se mais, conheçam-se mais. Mas eles iludem. É dificil fazer com que o outro sinta as coisas que estamos

2. Não estamos transcrevendo a fala: apenas memorizamos o que o cineasta parece ter dito. 
sentindo. É dificil compartilhar um sentimento, uma preocupação, uma dor. Mais difícil ainda, senão impossível, é trazê-lo para dentro de nós, instalá-lo no interior de nossa alegria ou de nossa dor, saber como os sentimos de fato. Pois a dor da gente, de fato, ninguém sabe. (2004, p. 98).

Essas constatações exigem, no caso da TV aberta brasileira, que a reflexão se torne ainda mais necessária, uma vez que seus sinais "invadem" mais de $90 \%$ dos domicílios do país, atingindo todas as faixas etárias e camadas sociais, devorando os traços mais autênticos de nossa miscigenada população. Uma propagação de sinais que espalha detritos numa sociedade em que as imagens podem ter missões mais profundas, principalmente quando se pensa como Norval Baitello Junior o faz no seguinte fragmento:

"as imagens são indeléveis e, através de novas configurações, elas conquistam uma segunda existência e ganham status, no dizer de (Bystrina, 1989) numa segunda realidade: a presença de uma ausência e seu oposto, a ausência de uma presença. Cabe lembrar que, nessa instancia, as imagens preservam vestígios dos significados que o termo imago tinha na língua latina. Isto é, elas podem significar entidades fantasmagóricas ou retratos de um morto". (2005, p. 20).

Segundo o autor acima citado e fazendo uma paráfrase das suas idéias, a defrontação com a morte possibilitou, ao homem, a invenção da cultura através do desenvolvimento de mundos e formas paralelos, ficcionais, jogos imaginativos com espaço e tempo do lúdico. Sendo assim, o homem passou a se reinventar e os entes criados por ele recebem tal investimento de crença que passam a determinar a vida do homem. Assim, o mundo da cultura possui esta característica: criar seres que atuam sobre os criadores. A descaracterização das imagens, em nosso caso podemos entender também como memórias culturais, fazem delas representações de representações, ilustrações 
de ilustrações, realidades cada vez mais distantes, abstratas e descarnadas de interioridades, vazias ou ocas. Para o autor, fantasmas, em soma, de aparição súbita e efêmera que serão sucessivamente substituídos por mais fantasmas, como uma imagem sucede a outra infinitamente, sem nunca levar a algo que não seja também uma imagem. $E$, a esse respeito, resume a questão citando a seguinte frase de Hans Belting: "as imagens convidam os vivos à fuga do corpo".

Relatando histórias populares ou não, as configurações imagéticas passam a ser utilizadas com outros interesses em fábulas que se descaracterizam e, pior, adquirem o atributo veracidade absoluta, seja qual for o contexto em que surgem, como se este fosse algo descartável e não fizesse parte da comunicação. Tal utilização mutila os relacionamentos instituídos pelos atos comunicativos, pois, como assinala Muniz Sodré

"toda e qualquer mensagem é tributária das circunstâncias ou do protocolo de emissão/recepção (produção e consumo). Uma lenda narrada por um contador de histórias numa tribo ou numa pequena comunidade, ao pé da fogueira, tem um vigor próprio atribuído pelo código oral de sua cultura. Através da TV ou de qualquer outro medium, a mesma lenda não teria força nenhuma, assim como não costumam ter sentido os ritos da cultura popular nordestina exibidos no vídeo." (Muniz Sodré, 1977, p. 57).

Sendo assim, sinto a desumanidade que há no pensamento daqueles que acreditam no principio de que, na TV comercial, uma história passa a ser um produto e este mesmo produto tem de ser consumível. Lembro-me do dia em que fui conhecer a escola onde estudaria o meu filho de dois anos e meio. Chamou-me a atenção o fato de que todos os bonecos ou bonecas tinham na face somente o nariz. Confesso que fiquei um pouco impressionado com essa imagem e perguntei à pedagoga o motivo: "As expressões dos rostos são criados na imaginação das crianças, de acordo com suas histórias, 
jamais poderiam fantasiar um momento de tristeza, em um boneco que ri o tempo todo." disse-me ela. Mas é claro, pensei, as emoções vêem de dentro para fora: do íntimo do ser, como deveria ocorrer no verdadeiro ato comunicativo, sem máscaras, sem distorções, e, então, percebi que nós, adultos, já estamos contaminados e envolvidos nesse jogo de ilusões das imagens e não intuímos que deixamos de sonhar os nossos sonhos: sonhamos os sonhos que nos são vendidos.

Entristece-me, enfim, pensar que a TV digital venha a ser utilizada apenas para tornar os nossos sonhos mais "reais", mas nítidos, como eu pensava serem os bonecos com nariz. E causa mais pena ainda que milhões e milhões de pessoas acreditem nisso, pois as grandes redes difundem quase que exclusivamente a qualidade da imagem como o maior trunfo do novo sistema.

\section{Bibliografa}

BAITELLO JUNIOR, Norval. 2005. A sociedade das imagens em série e a cultura do eco, in Revista F@ro, número 2.

MARCONDES FILHO, Ciro. 2004. Até que ponto de fato nos comunicamos? São Paulo, Editora Paulus.

SEGURA CONTRERA, Malena. 2007. Em meio ao desencanto: a comunicação fundada no pensamento mecânico-funcional. Trabalho apresentado ao Grupo de Trabalho "Epistemologia da Comunicação", do XVI Encontro da Compós, CD.

SODRÉ, Muniz. 1977. Monopólio da Fala. Rio de Janeiro: Editora Vozes. 